\title{
Street-level bureaucrats' action in the implementation of public policies in Brazil: a proposal for expanded analysis
}

\author{
FRANCESCO BONELLI ${ }^{12}$ \\ Antonio SÉrgio Araújo Fernandes ${ }^{2}$ \\ DENILSON BANDEIRA COÊLHO ${ }^{3}$ \\ JAMILI DA SILVA PALMEIRA ${ }^{2}$
}

${ }^{1}$ Instituto Federal de Educação, Ciência e Tecnologia da Bahia, Campus Avançado de Ubaitaba - BA, Brazil

2 Universidade Federal da Bahia / Núcleo de Pós-Graduação em AdMINISTRAÇão, SALVAdor - BA, Brazil

${ }^{3}$ Universidade de BrasílIa / INSTITUTO de CIÊNCIA Política, BrasílIA - DF, BRAZIL

\begin{abstract}
This article analyzes the multiple dimensions of street-level bureaucrats' action in the implementation of public policies in the Brazilian context. The study aims to contribute to understand the subject with an expanded analytical approach. Bibliographic research was carried out in academic digital databases, identifying and selecting national and international works, according to methodologically defined criteria. The publications were analyzed and organized according to the following conceptual categories: discretion, structures, individual action, and relations. From the tension regarding rules and discretion in public administration, the analysis and interpretation of these works showed: a) the need to compare, separately and jointly, three different perspectives of street-level bureaucrats' action (structural, individual action and relational perspectives); b) the need to understand the relationship of these perspectives in the implementation process itself. After the bibliographic review, hypotheses were formulated for an expanded analysis of the policy implementers' action, suggesting lines for future research on the subject. This article contributes to the debate on the subject with an unprecedented theoretical construct that seeks to integrate the three different analytical perspectives presented in a dialectical synthesis of the central concepts of the literature on street-level bureaucrats' implementation of public policies.
\end{abstract}

Keywords: Street-level bureaucrats. Implementation of public policies. Brazil. Rules. Discretion.

\section{A atuação dos burocratas de nível de rua na implementação de políticas públicas no Brasil: uma proposta de análise expandida}

\section{Resumo}

Neste artigo são analisadas as múltiplas dimensões da atuação dos burocratas de nível de rua no contexto brasileiro da implementação de políticas públicas. O objetivo do ensaio é contribuir para uma maior compreensão do tema com uma abordagem analítica expandida. Para tanto, foi realizada uma pesquisa bibliográfica em bases digitais acadêmicas que permitiu identificar e selecionar trabalhos nacionais e internacionais de acordo com critérios metodologicamente definidos. As publicações obtidas foram analisadas e organizadas em razão das seguintes categorias conceituais: discricionariedade, estruturas, ação individual e relações. Da tensão sobre regras e discricionariedade na administração pública, a análise e a interpretação desses textos evidenciaram: a) a necessidade de cotejar, separadamente e em conjunto, três diferentes perspectivas da atuação dos burocratas de nível de rua (a perspectiva estrutural, a de ação individual e a relacional); b) a necessidade de compreender a articulação dessas perspectivas no próprio processo de implementação. Após este trabalho de revisão bibliográfica foram formuladas hipóteses para uma análise expandida da atuação dos burocratas implementadores, traçando-se linhas para pesquisas futuras sobre o tema. Este ensaio contribui para o debate sobre o tema com um construto teórico inédito, que busca integrar as três diferentes perspectivas analíticas apresentadas numa síntese dialética dos conceitos centrais da literatura sobre a implementação de políticas públicas pelos burocratas de nível de rua.

Palavras-chave: Burocratas de nível de rua. Implementação de políticas públicas. Brasil. Regras. Discricionariedade.

\section{La actuación de los burócratas de la calle en la implementación de políticas públicas en Brasil: una propuesta de análisis ampliado}

\section{Resumen}

Este artículo analiza las múltiples dimensiones de la actuación de los burócratas de la calle en el contexto brasileño de la implementación de políticas públicas. El objetivo del ensayo es contribuir a una mejor comprensión del tema con un enfoque analítico ampliado. Para ello, se realizó una investigación bibliográfica en bases digitales académicas que permitió identificar y seleccionar trabajos nacionales e internacionales, de acuerdo con criterios metodológicamente definidos. Las publicaciones obtenidas fueron analizadas y organizadas de acuerdo con las siguientes categorías conceptuales: discrecionalidad, estructuras, acción individual y relaciones. A partir de la tensión sobre las reglas y la discrecionalidad en la administración pública, el análisis y la interpretación de estos textos evidenciaron: a) la necesidad de cotejar, separadamente y en conjunto, tres diferentes perspectivas de la actuación de los burócratas de la calle (la perspectiva estructural, la de acción individual y la relacional); b) la necesidad de comprender la articulación de esas perspectivas en el propio proceso de implementación. Después de este trabajo de revisión bibliográfica, se formularon hipótesis para un análisis ampliado de la actuación de los burócratas implementadores, trazando líneas para futuras investigaciones sobre el tema. Este ensayo contribuye al debate sobre el tema con un constructo teórico sin precedentes, que busca integrar las tres diferentes perspectivas analíticas presentadas en una síntesis dialéctica de los conceptos centrales de la literatura sobre la implementación de políticas públicas por los burócratas de la calle.

Palabras clave: Burócratas de la calle. Implementación de políticas públicas. Brasil. Reglas. Discrecionalidad.

Article submitted on November 07, 2018 and accepted for publication on March 25, 2019

[Translated version] Note: All quotes in English translated by this article's translator.

The authors thank the National Council for Scientific and Technological Development (CNPq) for its support through the Universal competition notice and the anonymous reviewers for their valuable contributions.

DOI: http://dx.doi.org/10.1590/1679-395177561x 


\section{INTRODUCTION}

The importance of the quality of state institutions in the regulation of human behavior, the provision of collective goods, the execution and inspection of public services, the formulation and implementation of public policies, and a country's socioeconomic development process are aspects that are widely acknowledged in literature (COÊLHO and FERNANDES, 2017; EVANS, 1995; HODGSON, 2006). Bureaucracy forms part of these institutions, which, according to Max Weber, consists of an organizational form of a sociopolitical system, administered hierarchically, based on rational-legal authority, in which regulations take precedence over individual interests and its agents' discretion (PEREIRA and MOTTA, 1987; PIRES, 2009; WEBER, 1968).

A study conducted by Evans and Rauch (1999) in 35 developing countries identified three structural characteristics that bureaucracy should have, so that a political-institutional environment conducive to economic growth may be constructed: recruitment based on meritocracy, the possibility of internal promotion and professional stability.

Therefore, the study of bureaucracy remains relevant and necessary, in order to understand how state-formulated policies translate in the administrative context. However, sociology of law works conducted since the 1960 s by authors such as Wilson (1967), followed by political science field research undertaken during the 1980s and 1990s, disseminated the understanding that the study of bureaucratic structures was insufficient to understand the translation of public policies in practice (DELEON, 1999; MATLAND, 1995; O'TOOLE JUNIOR, 1995; PARSONS, 1995). Lipsky (1980) adds that, to understand how public policies work in practice, the implementation phase also needs to be studied, in which bureaucrats' concrete actions are directed to citizen users.

Among other publications, Lipsky's (1980) seminal study is highlighted, in which policy implementers are identified as "streetlevel bureaucrats": state agents who, unlike mid-level bureaucrats (directors, managers and coordinators, etc.), provide their services directly to citizen users or monitor outsourced public services (HAM and HILL, 1993; LIPSKY, 1980). According to Lipsky (1980), for the bureaucrats who work with users on a daily basis, also called frontline or street-corner bureaucrats in literature (OLIVEIRA, 2012), such as police officers, social workers, nurses, doctors, teachers and judges, etc., adopting discretionary actions becomes inevitable, in order to guarantee policy application at the administrative level.

In the policy implementation process, these agents need to acquire specific skills - both technical-administrative and relational - to deal with the different actors involved in the uncertainties and occurrences not set out in regulations (CURRIE and PROCTER, 2005). The decisions of these bureaucrats, who are often part of the social context where they work, may fluctuate within a relatively wide margin of discretion, depending on their level of autonomy and the existence of clear and complete rules that delimit behavior and decision-making (LOTTA, 2010, 2014; LOTTA, PIRES and OLIVEIRA, 2014; OLIVEIRA, 2012; PIRES, 2009).

Public policy field research demonstrates the problem of incomplete regulations: legal standards - the result of political negotiation - often contain an amount of imprecision, indetermination and ambiguity in the language and definition of objectives (MATLAND, 1995; OLIVEIRA, 2012; ZAHARIADIS, 2007). A problem that is unresolved in the policy preparation phase is then transferred from the legislative to the administrative context; in other words, to the implementation phase, leaving the policy implementers with a margin for interpretation and discretion (OLIVEIRA, 2012). According to Matland (1995), this ambiguity of rules and objectives is a characteristic of policies that should not necessarily be regarded as a negative aspect. With a difference in the positions of studies that adopt a hierarchical (or top-down) approach to the implementation of public policies (PRESSMAN and WILDAVSKY, 1973; VAN METER and VAN HORN, 1975), the ambiguity of regulations has a certain use, since it may promote agreements between agents holding conflicting positions - particularly during the policy formulation phase - and encourage the testing and learning of new techniques, methodologies and objectives during their execution (MATLAND, 1995).

In this context, policy implementers, faced with an accumulated, high volume of demands, insufficient resources and overwhelmed by the cogs of the bureaucratic system, may deliberately look for shortcuts, molding and simplifying their work, and creating practices that enable users to be served according to a minimally acceptable quality standard (LIPSKY, 1980). Along this line of reasoning, as a consequence of street-level bureaucrats' action, Ham and Hill (1993) highlight the adoption 
of survival strategies and psychological coping mechanisms that translate into the adoption of stereotyped responses to users. This behavior may occasionally be related to the opportunistic exercise of power within public institutions: qualified professionals, such as doctors, lawyers, architects and teachers, etc., may act - because of their status - to the benefit of corporate interests, misrepresenting the missions of bureaucratic organizations (HAM and HILL, 1993).

Authors, such as Maynard-Moody and Musheno (2000), highlight that these regulations can form an unwelcome barrier between the public workers' actions and citizen users' requirements. According to accounts presented by street-level bureaucrats, the implementers, instead of placing themselves as obedient executors of regulations, may intentionally adopt a pragmatic judgment - based on community values, direct experience and handed-down wisdom - and prioritize responsible assistance, according to citizens' needs, justifying their decisions, due to the improvements achieved in policy execution, although this translates into more difficult, dangerous and undervalued work, etc. (MAYNARD-MOODY and MUSHENO, 2000).

More recently, Lotta, Pires and Oliveira's (2014) study, although focused on mid-level bureaucrats, provides an understanding of how the policy implementers' action unfolds in different perspectives, such as structural, individual action and relational, discussed in this paper in due course.

Advances in knowledge of the topic demonstrate the complexity of the implementation process, which, apart from being analyzed from the Weberian perspective of bureaucracy, with its structures and rules, needs to be studied from the standpoint of street-level bureaucrats' action and their interactions with the other actors involved (LOTTA, 2010, 2014; OLIVEIRA, 2012).

Despite this progress, Ferreira and Medeiros' (2016) recent work, which systematized literature on the behavioral factors of public policy implementers, shows the fragmentation between the different perspectives that make up the state-of-theart of public policy implementation. They demonstrate that, until then, the different perspectives adopted in implementing public policies, at the authors' convenience, result in mutually exclusive analyses (FERREIRA and MEDEIROS, 2016). We believe that this is a limiting factor for a fuller and more comprehensive understanding of the phenomenon, which could be better explained by combining the different approaches, as long as it is possible to justify merging the theories that sustain them.

For these reasons, this work is justified by the proposal to insert studies on the agenda of Brazilian public administration that, drawing on cross-referencing the different theoretical perspectives and evaluating their compatibility, provide an understanding of how the various dimensions of street-level bureaucrats' action combine and their effects on the policy implementation process.

Therefore, the aim of this article is to contribute towards guiding future research that adopts an expanded analytical approach and, based on the dilemma between control and discretion, enables the multiple dimensions of street-level bureaucrats' action and their combination with the implementation of national public policies to be obtained.

Thus, bibliographic research was undertaken (GIL, 2007; GRAY, 2012), which considered the following stages: a) the search and selection of national and international work on the topic; b) examination of the references contained in these, when related to the topic; c) identification of the relevant theoretical categories, and d) analysis, interpretation and a critical evaluation of the selected texts. The procedure used is justified by the nature of the problem, which comprises developing a relevant theoretical debate in the field of public administration.

The bibliographic research was undertaken on digital academic databases, searching for the title, abstract and keywords; the English terms "street-level bureaucrats", "public policy" and "implementation" were used, combined with the assistance of the Boolean operator "AND", and the corresponding terms in Portuguese "burocratas de nível de rua", "políticas públicas" and "implementação", with the assistance of the same operator, "AND". A time limit for the publication period of the work was not applied to these searches.

Based on these criteria, initially, 71 references were attained, which were further reduced on two occasions: the first was related to their suitability to the research topic, involving an analysis of the titles, abstracts and keywords, which reduced the number of texts to 36 ; the second was to remove duplicates, with 29 publications remaining. However, observing the references in the works collected in the first stage, a further 11 articles were identified and added to the 29, since they were related to the topic, resulting in the final total of 40 texts (it is noteworthy that the works used to discuss the general concept of implementation are not part of the final total). These publications were fully analyzed and organized into four central conceptual categories of academic debate: 1 ) discretion; 2 ) structures (including the concepts of organizations, hierarchies and rules); 3) individual action (including the concepts of agency, stewardship and cognitive variables), and 4) relations 
(including the concepts of interactions and mediation). The main references are demonstrated in Box 1 , organized into the four conceptual categories that will be discussed later on in this article.

\section{Box 1}

\section{Main publications organized by conceptual category}

\begin{tabular}{|c|l|}
\hline Conceptual category & \multicolumn{1}{|c|}{ References } \\
\hline Discretion & $\begin{array}{l}\text { Barrett (2004); Davis (1969); Floyd and Wooldridge (1992); Huising and Silbey } \\
\text { (2011); Hupe and Hill (2007); Lipsky (1980); Lotta (2010, 2014); Lotta, Pires and } \\
\text { Oliveira (2014); Pires (2009); Wilson (1967). }\end{array}$ \\
\hline Structures & $\begin{array}{l}\text { Coêlho and Fernandes (2017); Evans and Rauch (1999); Lupia and McCubbins } \\
\text { (1994); March and Olsen (2006); Pereira and Motta (1987); Wise (2004). }\end{array}$ \\
\hline Individual action & $\begin{array}{l}\text { Alchian and Demsetz (1972); Cline (2000); Davis, Schoorman and Donaldson } \\
\text { (1997); Elmore (1979); Fama and Jensen (1983); Evans and Rauch (1999); Kluvers } \\
\text { and Tippett (2011); Lima and D’Ascenzi (2013); Lupia and McCubbins (1994); } \\
\text { Maynard-Moody and Musheno (2012, 2015); Moe (1984); Donaldson and Davis } \\
\text { (1991); Muller and Surel (2002); Niskanen (1971); Osborne and Gaebler (1992); } \\
\text { Pollitt (1995); Van Slyke (2006). }\end{array}$ \\
\hline Relations & $\begin{array}{l}\text { Abers and Von Bülow (2011); Alexander, Lewis and Considine (2011); Berk, Galvan } \\
\text { and Hattam (2013); Coêlho, Cavalcante and Turgeon (2016); Huising and Silbey } \\
\text { (2011); Keiser (2010); Lima and D'Ascenzi (2013); Lotta (2010, 2014, 2018); Lotta, } \\
\text { Pires and Oliveira (2014); Pires (2009); Viana (2017). }\end{array}$ \\
\hline
\end{tabular}

Source: Elaborated by the authors.

With regards to the structure of this article, apart from the introduction, in which the topic and objective of the work are defined, policy implementation as a relevant topic in the field of public administration is discussed in the following section. In the third section, the debate introduced in national and international literature, on the dilemma between rules and discretion in bureaucracy, is presented. Following this, in the fourth section, the different perspectives adopted to analyze public policy implementers' action are presented and juxtaposed, corresponding to three of the four conceptual categories (structures, individual action and relations), previously used to organize the texts obtained in the bibliographic research. In this fourth section, contributions from the publications selected are drawn on and hypotheses are formulated for the formation of an expanded analysis of the topic, providing outlines for future research. In the fifth section, a duly substantiated theoretical justification is presented, that enables the different approaches and their respective theories in the theoretical construct proposed to be assembled. Final considerations are put forward in the sixth and last section.

\section{THE IMPLEMENTATION OF PUBLIC POLICIES AND THE FIELD OF PUBLIC ADMINISTRATION}

In Brazil, although some growth has taken place since the 1990s, studies on public policies are considered to be in the early stages, due to the multiplicity of under-developed approaches, a lack of coherence in lines of research, and dispersion of the subjects studied.

In fact, it is an under-institutionalized area, due to the deficiency of studies on public administration in the country, excessively concentrating on analyses of the decision-making processes (FARIA, 2003; LOTTA, 2014). More specifically, there are significant gaps at the theoretical level, particularly on the study of the implementation and evaluation phases, and an understanding of the mechanisms that influence policy performance (FARIA, 2003; HILL, 2003; LOTTA, 2014; PIRES, 2009).

Although traditional models still prevail in literature, there was an evolution in studies on the public policy cycle and the concept of implementing them. In an analysis of public policy implementation, it is important to distinguish between the (more traditional) top-down and bottom-up approaches. 
On the one hand, in 1970s mainstream literature, implementation is defined as the relation - linear and hierarchical - of the cause and effect between the objectives set in formulation and the actions undertaken in order to achieve them (BARRETT, 2004; PRESSMAN and WILDAVSKY, 1973; VAN METER and VAN HORN, 1975). The top-down approach also shows a clear Wilsonian separation between policy and administration: the policies formulated by political agents should simply be executed through bureaucracy (WILSON, 1887).

According to a detailed and empirically rigorous review of the state-of-the-art of implementation of public policies conducted by Saetren (2014), the first generation of studies on implementation is characterized by exploratory work in a relatively untouched field. The main concern of this research, which predominantly adopts the strategy of a single, qualitative case study (SAETREN, 2014), is explaining why the plans and objectives defined in the formulation phase of a public policy are not executed on their application. This means understanding the causes of the gap existing between what is planned and what is actually executed. The main exponents of this first generation of research on implementation are Pressman and Wildavsky (1973), whose central argument is that the complexity of the implementation process is the main cause of the failures observed in executing a policy. Although, according to Saetren (2014), the majority of this first generation work was published during the 1970s, its inauguration did not coincide with Pressman and Wildavsky's (1973) work. In fact, almost twenty articles were published on the topic before the 1970s, with four of them dating back to the late 1950 s (SAETREN, 2014).

On the other hand, a transition took place between the first and second generation of studies on implementation (SAETREN, 2014) both before and after 1980. In the second generation, in which Lipsky's (1980) above-mentioned study is highlighted, the reasons for the success or failure of executing public policy programs are explained, through the adoption of new analytical models, due to meetings that take place between the state and users, on the frontline, where policy implementers effectively apply policies (bottom-up perspective). Second generation studies are characterized by an evolution in theoretical-analytical models and the methodological paradigms adopted, where comparative studies start to prevail, particularly quantitative, to the detriment of single case studies (SAETREN, 2014).

Since the late 1980s, a third generation of studies has been establishing implementation as a process that develops gradually, through interaction among the various actors involved, with government intentions or political expectations as the starting point, and the perception of the impact of the public policies implemented as the end point (MATLAND, 1995; O'TOOLE JUNIOR, 1995; PARSONS, 1995). In practice, frontline implementers create policies, as they are executed (DELEON, 1999; FARIA, 2012). From this point of view, the processes matter more than the initial plans and the results cannot be predicted in advance, as they are prone to changes and contingencies (LOTTA, 2014; MAJONE and WILDAVSKY, 1984).

Therefore, according to the third generation approaches that develop a synthesis of the top-down and bottom-up perspectives (BARRETT, 2004) or focus on the dialectic relation between formulation and implementation, "the policy-action relationship" (BARRETT, 2004, p. 256), implementation can be understood as an execution and adaptation process, mediated by the government and its agents, of solutions initially designed in the formulation stage (LIMA and D'ASCENZI, 2013). According to Saetren (2014), greater progress is recognized at the methodological, rather than the theoretical level, in the third generation of studies, considering that theoretical questions would have evolved in a "much slower and more incremental" way (SAETREN, 2014, p. 84). According to Saetren (2014), in this generation of studies, the tendency that consists of adopting quantitative, comparative methodological strategies, based on a hypothetical-deductive logic, instead of qualitative inductive strategies, is emphasized. In O'Toole Junior's (2000) understanding, this aspect represents an indicator of a field of studies that is in a mature stage.

Considering the debate on top-down and bottom-up approaches and the results achieved in fifty years of research on implementation, it is observed that some of the main researchers on the topic, including Saetren (2014) and O'Toole Junior (2000), agree that substantial progress needs to be made, particularly at the theoretical level. Along the same line of reasoning as O'Toole Junior (2000), it is understood that scientific research on the implementation of public policies requires parsimonious analytical models that enable the juxtaposition and, if possible, the integration of different theoretical perspectives. 
Therefore, with the aim of overcoming the fragmentation of the different analytical perspectives and obtaining a more comprehensive understanding of the implementation process, we propose to include in the analysis the networks of organizations and individuals that make up the system, from the point of view of their interactions (LOTTA, 2014, 2018), in addition to the structural and individual action (or agency) perspectives. Public agents' discretion - a problem already identified during the 1960s, particularly within the domain of the sociology of law and organizational sociology (CAVALCANTI, LOTTA and PIRES, 2018) - will also be taken into account.

The theoretical proposal of this work requires a more critical look at the public policy formulation phase, frequently prepared from bargaining with divergent positions of various political actors, which results in imprecise and contradictory objectives, awash with omissions and reservations (OLIVEIRA, 2012; ZAHARIADIS, 2007). Consequently, the need for these gaps to be resolved in the implementation phase emerges; in other words, at the administrative level, through the action of policy implementers, who act as mediators, information centralizers and strategic intermediaries between political agents and citizens (LOTTA, PIRES and OLIVEIRA, 2014; OLIVEIRA, 2012).

Thus, the importance of policy implementation analysis at the micro level, focused on the exercise of discretion by frontline bureaucrats, who are able to make decisions for citizen users' requirements, is defended (MAYNARD-MOODY and MUSHENO, 2000). On the other hand, possible opportunistic behavior by public agents, who may willingly divert the purpose of their duties, going against established regulations and procedures, and affecting coordination between policy formulation and implementation, also needs to be carefully analyzed (COÊLHO and FERNANDES, 2017; FLOYD and WOOLDRIDGE, 1992; OLIVEIRA and ABRUCIO, 2011).

\section{THE DILEMMA BETWEEN RULES AND DISCRETION IN STREET-LEVEL BUREAUCRACY ACTION}

The debate on the control and discretion of bureaucracy initially began in the fields of sociology of law and organizational sociology, a few years before Lipsky presented his theory in 1969 "at the American Association of Political Science (APSA) annual meeting" (CAVALCANTI, LOTTA and PIRES, 2018, p. 229). The debate became popular in public administration literature with Lipsky's (1980) article on street-level bureaucrats' behavior. As Pires (2009) suggested, in literature there are controversies about public policy implementers' action: on the one hand, discretion, and control, in a Weberian view of the state, on the other.

In order to gain a better understanding of the term "discretion", Davis' (1969, p. 4) definition can be used, according to which "[...] a public officer has discretion whenever the effective limits on his power leave him free to make a choice among possible courses of action or inaction." According to Wilson (1967), the concept of control defines the capacity of bureaucracy to meet the government objectives defined in public policies.

According to Barrett (2004), an author who is openly influenced by Giddens' structuration theory (1994), to understand discretion it is important to identify the role of agents who know the system in which they operate from the inside: this knowledge enables the individuals to increase their bargaining capacity and discretionary power, within the domain of the implementation process itself, to challenge or defend the status quo, according to their values and interests.

In Hupe and Hill's (2007) vision, the existence of rules does not prevent the exercise of discretion by street-level bureaucrats. For these authors, any type of regulation - particularly one which regulates complex subjects, as occurs in various areas of public policies - needs to be interpreted and applied to the de facto situation. Therefore, the exercise of discretion is essential in the execution of policies, facing the need to make decisions that assist or exclude potential public service users or beneficiaries (HUPE and HILL, 2007).

Lotta (2010) highlights the existence of theoretical gaps in understanding policy implementers' actions and the influencing factors: the author analyzes street-level bureaucrats' behavior and the effects of their action on policy implementation, also considering the influence of institutional factors that limit discretion. Implementation is defined as a "[...] complex process that involves people, desires, needs, power, resources, disputes, knowledge and ignorance" (LOTTA, 2010, p. 15). Additionally, implementation is characterized by bureaucrats' communication and interactions with users and, therefore, consists of an adaptation and mediation process between the state and society, above all due to policy implementers' actions 
(LOTTA, 2010). In practice, institutional, organizational, individual and relational interests may overlap and alter the results of policy implementation, to the point that the same public policy comes to be applied in different ways (LOTTA, 2014; LOTTA, PIRES and OLIVEIRA, 2014).

In an ethnography conducted at Eastern University, Huising and Silbey (2011) define how "relational regulation", the approach used by managers to administer the imbalance between the design and application of legislation: the success of these agents does not consist of bridging the gap but of adapting the rules to the complexity and uncertainty of the local environment and keeping organizational activities within a range close to the initial regulatory specifications.

Along the same line of thinking, Pires (2009) compares the different management models - managerialist versus experimentalist - used for labor inspection in the state of Pernambuco, showing its impact in the respective implementation results. The research indicates that an approach less bound to predefined rules and objectives/targets and more open to the application of "diversified tactics" and solutions prepared with citizens, workers, trade unions, businessmen and other public bodies, etc. has proved to be more efficient in solving complex problems (PIRES, 2009, p. 168).

On the other hand, academics, such as Lupia and McCubbins (1994), have analyzed the problem of delegating policies from the legislative (principal) to the executive power (agents): legislative supervision in two forms - direct and centralized (police patrols) or indirect and decentralized (fire-alarms) - is the most common means to reduce the impact of the agency problem. According to the authors, the condition for the delegation to form an effective means to implement public policies and not become a type of abdication is that the legislators know how to create institutions that favor learning based on supervision (LUPIA and MCCUBBINS, 1994).

Similarly, Coelho and Fernandes' recent work (2017) on the Bolsa Família (direct transfer) program shows that formal rules, when understandable for the implementers and citizen users, can act as a behavior-modeling instrument for the actors involved, favoring learning in the principal-agent relationship, improving policy coordination and benefiting policy management.

It is also worth mentioning that excess autonomy could produce disproportionate differences in the results achieved by institutions in the same sector (FLOYD and WOOLDRIDGE, 1992), which occurred in public hospitals in the state of São Paulo, due to the considerable adaptation of regulations to local needs (OLIVEIRA and ABRUCIO, 2011).

Based on the different positions found in literature, a need to expand the analysis of public policy implementation through the prism of street-level bureaucrats is observed. Therefore, three different analytical perspectives of street-level bureaucracy action will be presented and juxtaposed in the following section, and hypotheses formulated that may contribute towards understanding the implementation process of national public policies, suggesting lines for future research on the topic. It should be noted that the conceptual category "discretion", discussed in this section, is not among the three analytical perspectives presented below, since it is understood that it develops in the dialectic tension between structure and agency molded by relations among agents (BARRETT, 2004); thus, it represents a cross-sectional concept that is related to each of the analytical perspectives of street-level bureaucrats' action, discussed in the next section.

The definition of the perspectives presented below is the result of efforts towards synthesis, focused on the construction of a model that is both comprehensive and parsimonious and may guide the performance of the empirical research required in Brazil, for a better understanding of the implementation of national public policies.

\section{PERSPECTIVES FOR AN EXPANDED ANALYSIS OF STREET-LEVEL BUREAUCRATS' ACTION}

In this section, based on selected literature, the structural, individual action and relational perspectives, adopted by Lotta, Pires and Oliveira (2014) in an analysis of mid-level bureaucrats' action, are discussed. However, they will be used here in an observation of street-level bureaucrats' action, and will enable the identification of possible paths, in order to advance research on the topic. It is emphasized that these perspectives correspond to three distinct forms of organizational governance, studied in the area of organizational theory, classified in hierarchies, market and networks (LOTTA, PIRES and OLIVEIRA, 2014; MÉNARD, 2012; WILLIAMSON, 1985, 1996). Additionally, it is observed that recent work on street-level bureaucrats in the implementation process identify the factors that mold policy implementers' behavior, grouping them into three large categories: managerial, personal and relational, and institutional factors (FERREIRA and MEDEIROS, 2016). It is understood 
that analogies can be established between the managerial, personal and relational factors, and the structural, individual action and relational perspectives.

The main texts selected for this article - as per Box 1 presented above - will now be presented and organized in order to discuss the three analytical perspectives (structural, individual action and relational), each corresponding to a different theoretical approach. The aim of this discussion is to construct the central argument on the combination and complementary nature of the three perspectives that analyze street-level bureaucrats' action from different, but not necessarily excluding, angles.

The structural perspective refers to the agents' compliance with formal rules, as a consequence of the position occupied in the bureaucratic hierarchy, and fulfilling the obligations and tasks associated to the position taken at the respective organization, in accordance with the Weberian view (LOTTA, PIRES and OLIVEIRA, 2014). Therefore, knowing about and analyzing the organization of the agency in question, its structure and regulations is required.

As suggested by March and Olsen (2006), agents at a certain institution may tend to align their actions to valid regulations, considered natural, fair, expected and legitimate, according to a common understanding. The regulations incorporate beliefs, institutional expectations, practices, routines, habits and codes of conduct etc., established over time and socially accepted. Therefore, these agents, instead of basing their decisions on cost-benefit calculations, recognize their organizational role and adapt their behavior to prescribed regulations, following the "logic of appropriateness", which is selecting the most appropriate course of action in a given legislative provision and specific situation (MARCH and OLSEN, 2006). Additionally, Wise (2004) highlights the priority that serving the public interest takes in bureaucrats' action, which is strongly conditioned by predefined institutional roles.

Managerial factors could be inserted within the domain of this structural perspective, which, according to Ferreira and Medeiros (2016, p. 790), include the set of "[...] resources, control systems, [...], performance standards" and other mechanisms used mainly within the organizational domain, by political agents and middle and high-level public agents to orientate policy implementers' actions towards the objectives established. However, according to authors such as May and Winter (2007) and Ferreira and Medeiros (2016), the influence of these managerial factors over policy implementers' behavior is very limited, essentially due to the distance between the agents who occupy hierarchically higher levels and where the decisions are taken, and the day-to-day actions performed. For this reason, managerial factors will not be considered in the following assumptions.

In addition to the aspects identified above, the quality of the rules plays an important role, since well-written, constantly improved regulations favor the observance and application of policies, and coordination with the agents involved, which may result in a higher standard of performance of services provided to the public (COÊLHO and FERNANDES, 2017). Thus, the importance of street-level bureaucrats' adherence to the objectives and rules defined in public policy for their implementation is understood. Therefore, it can be presumed that street-level bureaucrats' adherence to established rules and structures affects the implementation of public policies (Hypothesis I).

The perspective of individual action, in line with rational choice and agency theories, can be observed due to the presence or absence of incentives - such as rewards and punishments -, and the existence of monitoring mechanisms, so that agents' more or less cooperative (or more or less competitive) behavior can be analyzed (COÊLHO and FERNANDES, 2017; EVANS and RAUCH, 1999; LOTTA, PIRES and OLIVEIRA, 2014; LUPIA and MCCUBBINS, 1994; MOE, 1984; NISKANEN, 1971). According to agency theory, which adopts the premise of opportunistic behavior by individuals, when decisions are delegated to agents whose objectives are not in line with those of the principal, the result expected is a low level of performance (FAMA and JENSEN, 1983). However, the principal has instruments to minimize this conflict of interests, such as monitoring agents' behavior or - when the product of their work can be measured - the adoption of positive and negative incentives, i.e. awards and punishments respectively (ALCHIAN and DEMSETZ, 1972). The application of agency theory in the field of public administration was studied by Moe (1984), among other authors. According to this researcher, a series of principal-agent type relations can be identified at the various hierarchical levels of public administration, such as the relation between middle and highlevel bureaucrats and their subordinates (called frontline or street-level bureaucrats in this article). Important information problems take place in these hierarchical relations, such as adverse selection and moral hazard. Adverse selection relates to 
"hidden information", i.e., the behavior of one of the parties, focused on concealing information, beliefs and values that may encourage the other party to take different choices. Moral hazard consists of "hidden actions": this takes place when one of the parties adopts opportunistic behavior, such as avoiding or shirking their responsibilities, since they evaluate that the risk of suffering a punishment is less than the benefit resulting from selfish conduct (MOE, 1984).

Therefore, in the public administration context, characterized by inflexibility, a multitude of principals and agents, and a variety of objectives, it is predicted that there will be difficulties and high costs in applying these mechanisms. An example of bureaucratic conduct that deviates from its objectives is described by Niskanen (1971): bureaucracy agents may use their information advantages, in order to pressurize governments to increase the budget available to their institutions, so as to implement programs and increase the number of staff, comparable to what is undertaken by managers of departments at private companies.

In order to understand the perspective of individual action, it is important to emphasize that, since the early 1990s, concomitant with the wave of reforms that transform the public sector of numerous countries in the industrialized Western world, a hegemonic ideology - called New Public Management - spread throughout the field of public administration, focused on the application of business management models within the domain of public management, "reinventing government" (OSBORNE and GAEBLER, 1992). Among the remedies considered for reforms, measures such as cost reduction; the dissolution of traditional government organizations into agencies governed by specific contracts; setting performance targets and productivity indicators and the introduction of market or almost market mechanisms, etc., are envisaged (POLLITT, 1995). In this perspective, according to Cline (2000), policy objectives need to be clearly defined, and control and coordination mechanisms established, in order to align the interests of all the actors involved, so that public policies are effectively translated in the implementation phase. According to this logic of individual-rational action, consistent with rational choice and agency theories, an individual naturally tends to make decisions that are associated with his/her own personal interests, frequently deviating from organizational objectives. Consequently, the organization needs to adopt incentives and sanctions, to align individual behavior with institutional interests.

It should be highlighted that there are other theories in literature, such as stewardship theory, which defends that to explain the dynamic of principal-agent relations, values such as trust, cooperation, involvement and relational reciprocity, etc. need to be considered. According to these theories, the behavior of those involved, although not necessarily altruistic, may be cooperative, especially in the long-term; and agents may not only be motivated by extrinsic incentives - bonus, financial rewards and fines, etc. - but also intrinsic ones - reputation, autonomy, job satisfaction and stability, etc. (DAVIS, SCHOORMAN and DONALDSON, 1997; DONALDSON and DAVIS, 1991; KLUVERS and TIPPETT, 2011; VAN SLYKE, 2006).

Another approach to be considered in the analysis of individual action is that individuals interpret the reality and make choices based on their ideas, judgments, values and beliefs, etc. In other words, it admits the existence of a set of cognitive variables, apart from rationality, able to influence social actors in the decision-making process and their action (ELMORE, 1979; LIMA and D'ASCENZI, 2013; MAYNARD-MOODY and MUSHENO, 2012, 2015; MULLER and SUREL, 2002).

Irrespective of adopting the premises of agency theory or stewardship theory and admitting the influence of cognitive variables on individual behavior, the individual action perspective is relevant for an analysis of street-level bureaucrats' action, and to assess to what extent the existence of incentives influences the agents on the implementation of different public policies and the fulfillment of established targets (CLINE, 2000; COÊLHO and FERNANDES, 2017; LUPIA and MCCUBBINS, 1994; OSBORNE and GAEBLER, 1992; POLLITT, 1995). It admits the relevance of incentives - extrinsic or intrinsic - in the action of the streetlevel bureaucrats responsible for implementing public policies. Therefore, drawing on these considerations, independent of the policy implementer's behavior, as an "agent" or steward, it is assumed that the individual action of street-level bureaucrats affects the implementation of public policies (Hypothesis II).

Lastly, the relational perspective studies the bureaucratic agents' multiple interactions with other agents internal and external to the state. Through this prism, bureaucrats' involvement in implementing public policies is conceived within a comprehensive system of relations, which is connected by networks (HUISING and SILBEY, 2011; LOTTA, 2010, 2014; LOTTA, PIRES and OLIVEIRA, 2014; PIRES, 2009). Keiser (2010, p. 251) considers bureaucratic organizations as "[...] part of broader governance systems of interlocking organizations" and shows, specifically, how variability in the implementation of a public 
policy can be explained, based on reciprocal interaction and the exchange of information between frontline bureaucrats and the other agents involved (KEISER, 2010). As suggested by Abers and Von Bülow (2011), actors within the state can become an active part of larger networks that promote changes in the formulation and implementation of public policies. In other terms, the construction of social activism networks can take varying configurations and cross the boundaries between civil society organizations and the state, breaking away from pre-established forms and limits (ABERS and VON BÜLOW, 2011). In line with this vision, Viana (2017) defends that to understand the implementation of public policies, an analysis of the active relations that develop between bureaucrats and members of social movements needs to be included. In a recent study, in which he analyzes the performance of various actors involved in the Minha Casa Minha Vida (federal housing) - Entities program, the author highlights the role of social institutions and the families that become protagonists in the implementation of state housing policy, taking part in the definition of their housing needs (VIANA, 2017). In this process, the bureaucrats, despite being subject to legal, institutional and technical ties, on the one hand can take the role of negotiators with the higher levels of public power, acting strategically as partners of social movements; on the other hand, they may perform the function of mediators, making state decision more comprehensible for members of entities and users (VIANA, 2017).

From this relational perspective, Berk, Galvan and Hattam (2013) highlight the creative action of public agents, promoting processes of internal incremental change to the institutions; Huising and Silbey (2011) point out that the policy implementers, developing their capacity for negotiation, can achieve a superior performance by readapting regulations, according to the local context; Alexander, Lewis and Considine (2011) also defend that the study of interactions between politicians and bureaucrats and different network configurations may provide a better understanding of the levels of performance achieved by the government, and greater or less satisfaction of society, in relation to the services provided by local public institutions.

With regards to the importance of relations among political actors, Coêlho, Cavalcante and Turgeon (2016), in their study on the mechanisms of policy diffusion, describe how the influence exercised by certain governments in the adoption of policies by other governments spreads through formal or informal networks.

We deduced from our research that an analysis of street-level agents' multiple relations with other social actors (politicians, inspectors and users, etc.) is fundamental to understand the action of bureaucracy and the policy implementation process. In order to analyze policy implementers' actions, according to the relational perspective, the intensity and frequency of the interactions needs to be evaluated, as well as the quality and quantity of shared information on the program in question, since these interactions may promote mutual learning and align interests, affecting the implementation process. Consequently, it can be assumed that the street-level bureaucrats' interactions among themselves and the other actors involved affect the implementation of public policies (Hypothesis III).

In addition to the three perspectives described above, on which bases the respective hypotheses were formulated, institutional factors connected to public policies need to be observed, such as the political, economic and legal environment (COÊLHO and FERNANDES, 2017; OLIVEIRA and ABRUCIO, 2011), the influence of which requires analysis, within the domain of the implementation of public policy programs. Despite the progress recorded in some research (COÊLHO and FERNANDES, 2017; ZHAN, LO and TANG, 2013), little is yet known about the magnitude of the impact of exogenous factors in policy implementation.

\section{JUSTIFICATION FOR COMBINING THE DIFFERENT THEORETICAL APPROACHES AND PRESENTATION OF THE MODEL}

In this article, we analyzed the position of various authors selected during the bibliographic research, within each analytical perspective. However, we realized that the different perspectives and the respective theoretical approaches were not formed in isolation: the concepts of each one, if interpreted in a more open and flexible way, take a transverse dimension, as demonstrated below. Therefore, in this work, the three analytical perspectives - structural, individual action and relational - were placed in a dialectic relation, which provided a view beyond the limitations of each one and, therefore, their contribution towards an advance in knowledge on the topic. Thus, we sought a theoretical justification, which, based on studies already undertaken, would assist us in the task of joining apparently irreconcilable views. 
With this goal, we took a study by Lima and D'Ascenzi $(2013$, p. 105), which proposes a more fluid understanding of the concept of implementation, which could be understood as "[...] a process of using an idea that [...] is the consequence of the interaction between the intention (expressed in a plan) and the elements of the local contexts of the action." Therefore, these authors' proposal contributes towards an integration between two analytical models of the implementation: the first based on a sequential approach, centered on regulations and public policy formulation, in which implementation is conceived as operationalization of a plan within the administrative domain; the second model is based on a retrospective design, orientated by the discretion of the implementers, who strive to adapt the plan to the local context (LIMA and D'ASCENZI, 2013). According to Lima and D'Ascenzi $(2013$, p. 105), in order to conciliate the two approaches, the plan needs to be understood in a more open and flexible way, as a "set of provisions" that orientate the experimentation process. In fact, the plan is only put to the test through its implementation (it previously existed merely at a potential level) and the implementation process may generate new insights that are able to enhance the proposals initially set out in the plan. From this point of view, elements of the structural dimension, such as regulations, formal rules and plans, can be understood as socially constructed objects and, as such, subject to continual change and adaptation, as a result of human agency (BARRETT, 2004). Before they are executed, the plans also need to be interpreted by the agents (agency), who make use of their set of ideas, beliefs and values (cognitive variables) for this; lastly, the plans are mediated by organizational rules and structures and molded by power relations established in the workplace (LIMA and D'ASCENZI, 2013). This provides an understanding of how, within the domain of a complex system, such as the implementation of public policies, the structural dimension is confronted and renewed, in a dialectic tension, in a permanent confrontation with individual action - or agency (BARRETT, 2004), extrapolating the domain of rational choice and covering cognitive variables, such as ideas and values - and with the multiple relations established within and outside a given organizational environment.

Additionally, it is important to highlight that the public policy implementation process is currently characterized by the existence of new arrangements or hybrid forms (MÉNARD, 2012). In these organizational configurations, the traditional hierarchical structures of public bureaucracy co-exist and mix with market mechanisms (individual-competitive perspective) and networks of street-level organizations and public and private actors, such as companies, civil society associations, social groups and users, etc. (relational-interactive perspective). Thus, hybrid arrangements are configured in which the borders between the different organizations/agents involved become fuzzier: for example, third party company service providers are placed in public institution teams and the public employees may act as supervisors or inspectors of the services provided by private companies (BRODKIN, 2015; CAVALCANTI, LOTTA and PIRES, 2018; THOMANN, HUPE and SAGER, 2018).

It is also important to mention recent national research, such as that by Ferreira and Medeiros (2016), who accept the use of different perspectives, to identify the factors that mold street-level implementers' behavior. In their opinion, variables, such as discretion, regulations and self-interest, etc., are compatible and are mutually influenced in the implementation process itself (FERREIRA and MEDEIROS, 2016).

Based on an understanding of the above studies, particularly by Lima and D'Ascenzi (2013), whose position is supported by international authors, such as Majone and Wildavsky (1984) and Barrett (2004), Ferreira and Medeiros' (2016) article, and the above-mentioned work on the existence of hybrid arrangements and activities of street-level organizations in the execution of public policies, we understand that some central concepts from literature on implementation can be revisited and a more fluid interpretation of the approaches that sustain them can be formed. Plans, regulations and structures can be designed as potentialities or groups of intentions to be continually interpreted, accepted and improved by the actors involved (LIMA and D'ASCENZI, 2013); the individual action can be understood as agency, explained not only by incentives but also values, ideas, ideologies and judgments, etc., as defended by Maynard-Moody and Musheno (2012, 2015); and the interactions can be understood as constitutive of cooperative or confrontational relations (LOTTA, 2014, 2018), among different types of actors, holding multiple roles and responsible for achieving contradictory objectives (CHUN and RAINEY, 2005; DIXIT, 2002). A critical re-reading of these concepts enables us to approximate the theoretical approaches on which they are based dialectically, thereby justifying a juxtaposition of the respective analytical dimensions, namely the structural, individual action and relational perspectives, and their dialectic synthesis in a single analytical model.

As a contribution to knowledge on the topic, this study proposes that future research adopts a dialectic and comprehensive vision of the three analytical perspectives, in order to test, at the empirical level, that in street-level bureaucrats' daily activities, 
the need to adhere to the regulations and structures in place, agents' individual actions and their reciprocal interactions, and those with other social actors, co-exist and are mutually influenced in the complex decision-making process that permeates the provision of public services to citizens. Therefore, it is presumed that adherence to established rules and structures, street-level bureaucrats' individual actions and their interactions - among themselves and with other actors involved jointly affect the implementation of public policies (Hypothesis IV).

Therefore, for an expanded analysis of street-level bureaucrats' action in the implementation of national public policies, we propose the adoption of a theoretical construct, synthesized in the model demonstrated in Figure 1 that, identifying the main conceptual dimensions and categories raised in this research, seeks to integrate the three analytical perspectives presented.

Figure 1

Model for an expanded analysis of policy implementers' action

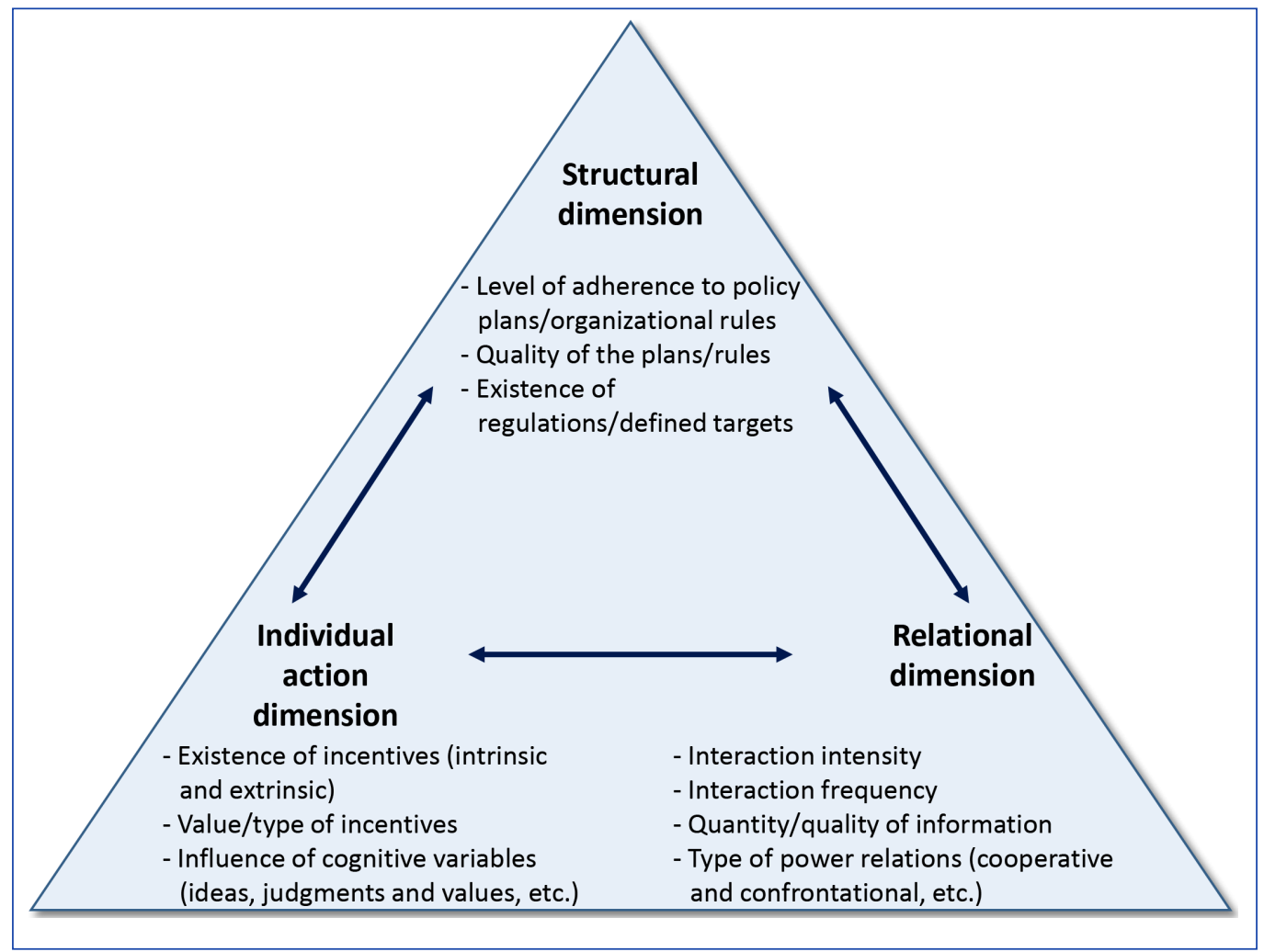

Source: Elaborated by the authors.

\section{FINAL CONSIDERATIONS}

The bibliographic research undertaken allowed us to reinforce an understanding of the importance of the debate - conducted in the national and international areas - between rules and discretion in the implementation of public policies, both at theoretical and empirical levels.

At the theoretical level, this research enabled us to formulate hypotheses that aim to form an expanded analysis of policy implementers' action and the implementation process itself, based on recognizing the juxtaposition and compatibility of different theoretical perspectives, considered until the present day, at least at the national level, as mutually exclusive in research on the topic. We believe that the main contribution of this work is of proposing compatibility and integration of the three different approaches in a single theoretical construct, through an unprecedented theoretical model. 
Validation of these assumptions at the empirical level requires comparative analyses between different national public policy programs and various bureaucrat profiles, regarding skills, education, type of entrance into public service, work routines and external constraints, etc. The profiles of bureaucrats and their involvement in the implementation process could be better understood, by evaluating their greater or less proximity to citizens and, in particular, considering the type of power exerted, which, depending on the policy, could fluctuate between the guarantee of benefits and delivery of services to users (as in the case of health and social workers and teachers, etc.) and the inhibition and/or repression of irregularities/illegal actions through inspection and coercion (as in the case of police officers, Federal Inland Revenue auditors or regulatory agency inspectors who work in environmental, agricultural and sanitary surveillance areas, among others).

To this end, future research could enable the model to be tested in different empirical contexts using comparative analyses, such as multiple case studies, which, for example, evaluate how the different analytical perspectives of street-level bureaucrats' action translate in practice, comparing agents with variable profiles who serve different categories of users or guarantee the defense of diffuse interests.

It is highlighted that the majority of studies in Brazil have focused on the analysis of policy implementers that belong to the first typology (deliverers of public services, who select and/or assist beneficiaries). In the bibliographic research performed in this work, we were not able to identify national studies that had given priority to analyzing frontline bureaucrats whose work focuses on inhibiting the conduct of offenders. Along this line of thinking, the model proposed enables an evaluation of the extent to which each perspective contributes towards execution of a given public policy. It can be assumed that frontline agents who are more focused on supervisory and punitive activities are more inclined to adhere to rules and formal structures, compared to agents with more focus on allocating benefits to eligible citizens. On the other hand, a priori, we cannot exclude that these agents' action may be influenced by the existence of incentives (financial or otherwise) and/or interaction with other public or private social actors.

Additionally, this study identified the need to understand the relation between factors associated to the dimensions of streetlevel bureaucrats' action and how public policy is implemented, to the point of being adapted, or otherwise, to the local context and/or to the de facto situation, thereby affecting the very nature of the policy. It therefore becomes necessary to conduct investigations that evaluate the phenomena that affect the implementation process in different circumstances at micro level.

Therefore, a possible application of the theoretical construct proposed may be formed of an analysis of the relation between competencies/characteristics - intellectual, emotional and cognitive, etc. - of a given street-level bureaucrat profile and the type of policy to be implemented. For example, it can be assumed that for a policy that needs to be adapted to a local context, the relational perspective and certain variables of the individual action perspective may have a predominant weight on a street-level bureaucrat's action, compared with the structural perspective. Vice versa, for a policy that intends to be more standardized, it is assumed that a structural perspective prevails.

Evidently, they are working hypotheses based on the theoretical construct proposed but they require testing at the empirical level.

Further analyses of policy implementers' action may compare the effects of different political-institutional contexts on the same policy program, in distinct timeframes. For example, how the varying policy guidelines at the core of government, taken in different presidential terms in Brazil, affect policy implementers' action in different areas of public policies could be investigated. Thus, it is appropriate to reflect on the need to develop studies that focus on the policy sectors that have not been explored in detail, such as agriculture, the environment, work and employment, among others.

Also, bearing in mind the introduction of legislative reforms to expand the involvement of non-state organizations - called street-level organizations in recent literature - in the provision of public services, through the growing use of hybrid, publicprivate arrangements, we consider it opportune to investigate how the dimensions proposed in the model apply and are combined in street-level bureaucrats and service providers' action and, consequently, to what extent they affect how public policies are implemented and delivered to citizens.

This study presents a series of limitations that may represent aspects to be further developed in future research, namely: 
- The need to expand bibliographic research, consulting other authors from the field of sociology, in addition to the authors already considered, mainly located in the fields of political science and public administration. Among these, Vincent Dubois (1999) should be mentioned, who developed a critical approach on public policy analysis; Flávio Eiró (2017), who analyzed the influence of policy implementers' opinions on the exercise of discretion; and other authors who study the social consequences of implementation, such as inequalities (CAVALCANTI, LOTTA and PIRES, 2018);

- Further cross-checking of the three perspectives presented (structural, individual action and relational), by presenting the advantages and disadvantages of each one, from the point of view of policy implementation;

- Select the most appropriate methodology to analyze - in future research - the implementation process of a certain policy and then evaluate its performance from the point of view of its effectiveness, considering that a well-executed policy does not necessarily fully satisfy users;

- Further discussion on the quality of rules and the study of incentives, distinguishing between extrinsic and intrinsic incentives and the cognitive variables, and how all these factors, taken separately or together, can affect policy implementers' behavior;

- A deeper understanding of the importance of career bureaucrats to the state and society, their role, values, ideas, other cognitive aspects, and the characteristics that enable them to implement public policies, particularly in the current context, characterized by new public-private arrangements.

In Brazil, there is a need to develop empirical studies which better understand the role of bureaucracy - especially at streetlevel - and that of other public and private actors in the execution of different policies and which provide innovative solutions for the decision-making process in the implementation phase. We believe that research conducted along the lines suggested in this research could not only contribute towards the theoretical advances required in the field of national public administration, but also in the formulation of solutions for the enhancement, qualification and innovation of the decision-making process by state agents and the other social actors involved in the implementation of public policies. 
Street-level bureaucrats' action in the implementation of public policies in Brazil: a proposal for expanded analysis
Francesco Bonelli| Antonio Sérgio Araújo Fernandes Denilson Bandeira Coêlho | Jamili da Silva Palmeira

\section{REFERENCES}

ABERS, R.; VON BÜLOW, M. Movimentos sociais na teoria e na prática: como estudar o ativismo através da fronteira entre estado e sociedade? Sociologias, v. 13, n. 28, p. 52-84, 2011.

ALCHIAN, A. A.; DEMSETZ, H. Production, information costs, and economic organization. The American Economic Review, v. 62, n. 5, p. 777-795, 1972.

ALEXANDER, D.; LEWIS, J. M.; CONSIDINE, M. How politicians and bureaucrats network: a comparison across governments. Public Administration, v. 89, n. 4, p. 1274-1292, 2011.

BARRETT, S. M. Implementation studies: time for a revival? Personal reflections on 20 years of implementation studies. Public Administration, v. 82, n. 2, p. 249-262, 2004.

BERK, G.; GALVAN, D. C.; HATTAM, V. (Eds.). Political creativity: reconfiguring institutional order and change. Pennsylvania: University of Pennsylvania Press, 2013.

BRODKIN, E. The inside story. In: HUPE, P.; HILL, M.; BUFFAT, A. (Eds.). Understanding street level bureaucracy. Bristol: Policy Press, 2015. Part One, Introdc.

CAVALCANTI, S.; LOTTA, G. S.; PIRES, R. R. C. Contribuições dos estudos sobre burocracia de nível de rua. In: PIRES, R.; LOTTA, G.; OLIVEIRA, V. E. (Orgs.). Burocracia e políticas públicas no Brasil: interseções analíticas. Brasília: Ipea/ Enap, 2018. cap. 9, p. 227-246.

CHUN, Y. H.; RAINEY, H. G. Goal ambiguity and organizational performance in US federal agencies. Journal of Public Administration Research and Theory, v. 15, n. 4, p. 529-557, 2005.

CLINE, K. D. Defining the implementation problem: Organizational management versus cooperation. Journal of Public Administration Research and Theory, v. 10, n. 3, p. 551-572, 2000.

COÊLHO, D. B.; CAVALCANTE, P.; TURGEON, M. Mecanismos de difusão de políticas sociais no Brasil: uma análise do Programa Saúde da Família. Revista de Sociologia e Política, v. 24, n. 58, p. 145-165, 2016.

COÊLHO, D. B.; FERNANDES, A. S. A. Rules matter: determinants of bureaucratic control in the Bolsa Família Program. RAP - Brazilian Journal of Public Administration, v. 51, n. 5, p. 689-707, 2017.

CURRIE, G.; PROCTER, S. J. The antecedents of middle managers' strategic contribution: the case of a professional. Journal of Management Studies, v. 42, n. 7, p.99-117, 2005.

DAVIS, J, H.; SCHOORMAN, F. D.; DONALDSON, L. Toward a Stewardship Theory of Management. Academy of Management Review, v. 22, n. 1, p. 20-47, 1997.

DAVIS, K. C. Discretionary justice. Baton Rouge: Louisiana State University Press, 1969.

DELEON, P. The missing link revisited: contemporary implementation research. Review of Policy Research, v. 16, n. 3-4, p. 311-338, 1999.

DIXIT, A. Incentives and organizations in the public sector: an interpretative review. Journal of Human Resources, v. 37, n. 4, p. 696-727, 2002.

DONALDSON, L.; DAVIS, J. H. Stewardship theory or agency theory: CEO governance and shareholder returns. Australian Journal of management, v. 16, n. 1, p. 49-64, 1991.
DUBOIS, V. La vie au guichet: relation administrative et traitement de la misère. Paris: Economica, 1999. (Collection Études Politiques).

EIRÓ, F. O Programa Bolsa Família e os pobres "não merecedores": poder discricionário e os limites da consolidação de direitos sociais. In: IPEA - Instituto de Pesquisa Econômica Aplicada. Implementação de políticas e desigualdades. Boletim de Análise Político-Institucional, n. 13 , 2017. p. 65-70.

ELMORE, R. F. Backward mapping: Implementation research and policy decisions. Political Science Quarterly, v. 94, n. 4, p. 601-616, 1979.

EVANS, P. B. Embedded autonomy: states and industrial transformation. Princeton: Princeton University Press, 1995.

EVANS, P. B.; RAUCH, J. E. Bureaucracy and growth: a cross-national analysis of the effects of "Weberian" state structures on economic growth. American Sociological Review, v. 64, n. 5, p. 748-765, 1999.

FAMA, E. F.; JENSEN, M. C. Separation of ownership and control. Journal of Law and Economics, v. 26, n. 2, p. 301-325, 1983.

FARIA, C. A. P. Ideias, conhecimento e políticas públicas: um inventário sucinto das principais vertentes analíticas recentes. Revista Brasileira de Ciências Sociais, v. 18, n. 51, p. 21-30, 2003.

FARIA, C. A. P. Introdução. In: FARIA, C. A. P. (Org.). Implementação de políticas públicas: teoria e prática. Belo Horizonte: Ed. PUC Minas, 2012. p. 7-18.

FERREIRA, V. D. R. S.; MEDEIROS, J. J. Fatores que moldam o comportamento dos burocratas de nível de rua no processo de implementação de políticas públicas. Cadernos EBAPE.BR, Rio de Janeiro, v. 14, n. 3, p. 776-793, 2016.

FLOYD, S. W.; WOOLDRIDGE, B. Middle management involvement in strategy and its association with strategic type: a research note. Strategic Management Journal, v. 13, n. S1, p. 153-167, 1992.

GIDDENS, A. The Constitution of Society. Oxford: Polity Press, 1994.

GIL, A. C. Como elaborar projetos de pesquisa. 4. ed. São Paulo: Atlas, 2007.

GRAY, D. E. Pesquisa no mundo real. Tradução: Roberto Cataldo Costa. Revisão técnica: Dirceu da Silva. 2. ed. Porto Alegre: Penso, 2012.

HAM, C.; HILL, M. O processo de elaboração de políticas no estado capitalista moderno. Tradução: Renato Amorim e Renato Dagnino. Adaptação e revisão: Renato Dagnino. Campinas: DPCTUNICAMP, 1993.

HILL, H. C. Understanding implementation: street-level bureaucrats' resources for reform. Journal of Public Administration Research and Theory, v. 13, n. 3, p. 265-282, 2003.

HODGSON, G. M. What are institutions? Journal of Economic Issues, v. 40, n. 1, p. 1-25, 2006.

HUISING, R.; SILBEY, S. S. Governing the gap: forging safe science through relational regulation. Regulation \& Governance, v. 5, n. 1, p. 14-42, 2011.

HUPE, P.; HILL, M. Street-Level bureaucracy and public accountability. Public Administration, v. 85, n. 2, p. 279-299, 2007. 
Street-level bureaucrats' action in the implementation of public policies in Brazil: a proposal for expanded analysis
Francesco Bonelli |Antonio Sérgio Araújo Fernandes Denilson Bandeira Coêlho | Jamili da Silva Palmeira
KEISER, L. R. Understanding street-level bureaucrats' decision making: determining eligibility in the social security disability program. Public Administration Review, v. 70, n. 2, p. 247-257, 2010.

KLUVERS, R.; TIPPETT, J. An exploration of stewardship theory in a Not-for-Profit organisation. Accounting Forum, v. 35, n. 4, p. 275284, 2011.

LIMA, L. L.; D’ASCENZI, L. Implementação de políticas públicas. Revista de Sociologia e Política, v. 21, n. 48, p. 101-110, 2013.

LIPSKY, M. Street-level bureaucrats. Nova York: Russel Sage, 1980.

LOTTA, G. S. Implementação de políticas públicas: o impacto dos fatores relacionais e organizacionais sobre a atuação dos burocratas de nível de rua no Programa Saúde da Família. 2010. Tese (Doutorado em Ciência Política) - Faculdade de Filosofia, Letras e Ciências Humanas, Universidade de São Paulo, São Paulo, 2010.

LOTTA, G. S. Agentes de implementação: uma forma de análise de políticas públicas. Cadernos Gestão Pública e Cidadania, v. 19, n. 65, p. 186-206, 2014.

LOTTA, G. S. Burocracia, redes sociais e interação: uma análise da implementação de políticas públicas. Revista de Sociologia e Política, v. 26, n. 66, p. 143-173, 2018.

LOTTA, G. S.; PIRES, R. R. C.; OLIVEIRA, V. E. Burocratas de médio escalão: novos olhares sobre velhos atores da produção de políticas públicas. Revista do Serviço Público, v. 65, n. 4, p. 463-492, 2014.

LUPIA, A.; MCCUBBINS, M. D. Learning from oversight: fire alarms and police patrols reconstructed. Journal of Law, Economics \& Organization, v. 10, n. 1, p. 96-125, 1994.

MAJONE, G.; WILDAVSKY, A. B. Implementation as evolution. In: PRESSMAN, J. L.; WILDAVSKY, A. B. (Eds.). Implementation. 3. ed. Berkeley: University of California Press, 1984.

MARCH, J. G.; OLSEN, J. P. The Logic of Appropriateness. In: GOODIN, R. E.; MORAN, M.; REIN M. (Eds.). The Oxford Handbook of Public Policy. Oxford, NY: Oxford University Press, 2006.

MATLAND, R. E. Synthesizing the implementation literature: The ambiguity-conflict model of policy implementation. Journal of Public Administration Research and Theory, v. 5, n. 2, p. 145-174, 1995.

MAY, P. J.; WINTER, S. C. Politicians, managers, and street-level bureaucrats: Influences on policy implementation. Journal of Public Administration Research and Theory, v. 19, n. 3, p. 453-476, 2007

MAYNARD-MOODY, S.; MUSHENO, M. State agent or citizen agent: Two narratives of discretion. Journal of Public Administration Research and Theory, v. 10, n. 2, p. 329-358, 2000.

MAYNARD-MOODY, S.; MUSHENO, M. Social equities and inequities in practice: street-level workers as agents and pragmatists. Public Administration Review, v. 72, n. s1, p. 16-23, 2012.

MAYNARD-MOODY, S.; MUSHENO, M. Playing the rules: discretion in social and policy context. In: HUPE, P.; HILL, M.; BUFFAT, A. (Eds.). Understanding street-level bureaucracy. Bristol: Policy Press, 2015. p. $169-186$.

MÉNARD, C. Hybrid modes of organization. Alliances, joint ventures, networks, and other 'strange' animals. In: GIBBONS, R.; ROBERTS, J. (Eds.). The Handbook of Organizational Economics. Princeton: Princeton University Press, 2012. p. 1066-1108.
MOE, T. M. The new economics of organization. American Journal of Political Science, v. 28, n. 4, p. 739-777, 1984

MULLER, P.; SUREL, Y. A análise das políticas públicas. Pelotas: Educat, 2002.

NISKANEN, W. A. Bureaucracy and representative government. Chicago: Aldine Atherton, 1971.

OLIVEIRA, A. Burocratas da linha de frente: executores e fazedores das políticas públicas. Revista de Administração Pública, Rio de Janeiro, v. 46, n. 6, p. 1551-1573, 2012.

OLIVEIRA, V. E.; ABRUCIO, F. L. Entre a política e a burocracia: a importância dos burocratas de nível médio para a produção de políticas públicas em saúde e educação. In: ENCONTRO ANUAL DA ANPOCS, 35., 2011, Caxambu (MG). Anais... Minas Gerais: ANPOCS, 2011.

OSBORNE, D.; GAEBLER, T. Reinventing government: how the entrepreneurial spirit is transforming the public sector. Reading: Addison-Wesley, 1992.

O'TOOLE JUNIOR, L. J. Rational choice and policy implementation: Implications for interorganizational network management. The American Review of Public Administration, v. 25, n. 1, p. 43-57, 1995.

O'TOOLE JUNIOR, L. J. Research on policy implementation: Assessment and prospects. Journal of Public Administration Research and Theory, v. 10, n. 2, p. 263-288, 2000.

PARSONS, W. Public policy: an introduction to the theory and practice of policy analysis. Cheltenham: Edward Elgar, 1995.

PEREIRA, L. C. B.; MOTTA, F. C. P. Introdução à organização burocrática. São Paulo: Brasiliense, 1987.

PIRES, R. R. C. Burocracia, discricionariedade e democracia: alternativas para o dilema entre controle do poder administrativo e capacidade de implementação. Cadernos Gestão Pública e Cidadania, v. 14, n. 54, p. 147-187, 2009.

POLLITT, C. Justification by works or by faith? Evaluating the new public management. Evaluation, v. 1, n. 2, p. 133-154, 1995.

PRESSMAN, J. L.; WILDAVSKY, A. B. Implementation: how great expectations in Washington are dashed in Oakland; or, why it's amazing that federal programs work at all. Berkeley: University of California Press, 1973.

SAETREN, $\mathrm{H}$. Implementing the third generation research paradigm in policy implementation research: An empirical assessment. Public Policy and Administration, v. 29, n. 2, p. 84-105, 2014.

THOMANN, E.; HUPE, P.; SAGER, F. Serving many masters: Public accountability in private policy implementation. Governance, v. 31 n. 2, p. 299-319, 2018.

VAN METER, D. S.; VAN HORN, C. E. The policy implementation process: A conceptual framework. Administration \& Society, v. 6, n. 4, p. 445-488, 1975.

VAN SLYKE, D. M. Agents or stewards: Using theory to understand the government-nonprofit social service contracting relationship. Journal of Public Administration Research and Theory, v. 17, n. 2, p. 157-187, 2006.

VIANA, R. R. Reconfigurando a relação entre estado - sociedade: um olhar para ação dos diferentes atores no processo de produção do Programa Minha Casa Minha Vida-Entidades. In: ENCONTRO DA ANPAD, 
Street-level bureaucrats' action in the implementation of public policies in Brazil: a proposal for expanded analysis
Francesco Bonelli | Antonio Sérgio Araújo Fernandes Denilson Bandeira Coêlho | Jamili da Silva Palmeira
41., 2017, São Paulo. Anais eletrônicos... São Paulo: ANPAD, 2017. Available at: <http://www.anpad.org.br/ anpad/eventos.php?cod_ evento=1\&cod_evento_edicao=89\&cod_edicao_subsecao=1453\&cod_ edicao_trabalho=23081>. Accessed on: Oct. 15, 2017.

WEBER, M. Economy and society. New York: Bedminster Press, 1968.

WILLIAMSON, O. E. The economic institutions of capitalism: firms, markets, relational contracting. New York: Free Press, 1985.

WILLIAMSON, O. E. The mechanisms of governance. Oxford: Oxford University Press, 1996.

WILSON, J. Q. The bureaucracy problem. The Public Interest, n. 6, p. 3-9, 1967. Available at: <https://nationalaffairs.com/public_interest/ detail/the-bureaucracy-problem>. Accessed on: Oct. 30, 2018.
WILSON, W. The study of administration. Political Science Quarterly, v. 2, n. 2, p. 197-222, 1887.

WISE, L. R. Bureaucratic Posture: On the Need for a Composite Theory of Bureaucratic Behavior. Public Administration Review, v. 64, n. 6, p. 669-680, 2004.

ZAHARIADIS, N. The multiple streams framework: Structure, limitations, prospects. In: SABATIER, P. A.; WEIBLE, C. M. (Eds.). Theories of the policy process. 2. ed. Boulder: Westview Press Boulder, 2007. p. 65-92.

ZHAN, X.; LO, C. W. H.; TANG, S. Y. Contextual changes and environmental policy implementation: a longitudinal study of street-level bureaucrats in Guangzhou, China. Journal of Public Administration Research and Theory, v. 24, n. 4, p. 1005-1035, 2013.

Francesco Bonelli

ORCID: https://orcid.org/0000-0001-8628-9068

PhD student in Administration at the Post-Graduation in Administration Center of the Federal University of Bahia (NPGA/EA-UFBA); Master in Administration from the Federal University of Bahia (NPGA/EA-UFBA); Professor at the Federal Institute of Education, Science and Technology of Bahia (IFBA); Administrator at the Federal University of Bahia (UFBA), Salvador - Bahia, Brazil. E-mail: francescobonelli@gmail.com

Antonio Sérgio Araújo Fernandes

ORCID: https://orcid.org/0000-0002-4171-7759

PhD in Political Science from the University of São Paulo (USP); Master in Urban Development from the Federal University of Pernambuco (UFPE); Associate Professor and Researcher at the Post-Graduation in Administration Center of the Federal University of Bahia (NPGA/EA-UFBA), Salvador - Bahia, Brazil. E-mail: asaferna@outlook.com

Denilson Bandeira Coêlho

ORCID: https://orcid.org/0000-0003-0125-4347

PhD and Master in Political Science from the Federal University of Pernambuco (UFPE); Associate Professor I at the Institute of Political Science, University of Brasília, (IPOL/UnB), Brasília - DF, Brazil. E-mail: denilsonbc@unb.br

Jamili da Silva Palmeira

ORCID: https://orcid.org/0000-0002-6726-7258

National Council for Scientific and Technological Development (CNPq) scholarship holder; Master's student in Administration at the Post-Graduation in Administration Center of the Federal University of Bahia (NPGA/EA-UFBA), Salvador - Bahia, Brazil. E-mail: jamilipalmeira.adm@gmail.com 